\title{
Las nuevas cepas y variantes.
}

\author{
The new strains and variants.
}

\begin{abstract}
Agustín Zerón*
Nadie sabe hacia dónde se dirige el SARS-CoV-2, pero lo único que sabemos con certeza es que mientras haya personas no vacunadas, las variantes con nuevas propiedades clínicas son posibles y pueden atormentarnos en los próximos años. Jeremy Luban

sería: ¿es la variante o la vacunación lo que ha disminuido los índices de hospitalización, severidad y muerte? No hay duda, la vacunación ha resultado una excelente estrategia epidemiológica. En países como Australia, donde la vacunación ya es un mandato obligatorio, quien no se vacune puede recibir una multa de 3,600€. La estrategia no es optativa.
\end{abstract}

$I^{n}$ niciar el año con buenas noticias es acompañar el ánimo para ver la luz al final del túnel. Este primer bimestre de 2022 hemos recibido noticias de países que han disminuido restricciones en pleno pico de la pandemia. Aun con los altos índices de infección por la variante ómicron, el número de internos y casos graves ha disminuido. La medida de restricción sólo obedece a los altísimos porcentajes de vacunación donde la variante ómicron ha dejado de verse como una amenaza. Dinamarca fue la primera nación en declarar el «final de la pandemia», el coronavirus ya no es un peligro crítico, al menos en algunos países. Las medidas de mitigación y contención han funcionado, pero lo que más ha revolucionado el control es el $80 \%$ de la población vacunada con dos dosis, y hasta $60 \%$ de los mayores de 12 años ya cuentan con tres dosis en dicho país.

La triste realidad es que la mayor parte de personas en el mundo todavía no está vacunada. Y México, penosamente, está muy lejos de llegar a los niveles de salud de los países escandinavos. Simplemente, si la vacunación sigue como hasta ahora, México podría alcanzar $80 \%$ de personas vacunadas a principios o mediados del 2023, así lo han estimado los expertos de John Hopkins.

La ola de ómicron ha sido la más alta en la pandemia, pero también es cierto que ha sido la menos mortal. La pregunta

\section{MUTACIONES, VARIANTES Y CEPAS}

La naturaleza de los virus es mutar. Todos los virus cambian (o mutan) a medida que se replican y se propagan en una población. Las mutaciones son los cambios genéticos que sufren los virus al pasar de una persona a otra, cada persona aporta algunos genes para la supervivencia del virus. Una mutación es un cambio único en el genoma del virus (código genético). Las mutaciones ocurren con mucha frecuencia, pero sólo a veces modifican las características del virus.

Las variantes son agrupaciones de distintas mutaciones formando «ramas» o linajes. Un linaje es un grupo de virus estrechamente relacionados con un ancestro común. El SARS-CoV-2 tiene muchos linajes; todos causan COVID-19. Una variante es un genoma (código genético viral) que puede incluir una o más mutaciones. En algunos casos, un grupo de variantes con cambios genéticos similares, como un linaje o grupo de linajes, puede ser designado por las organizaciones de salud pública como una variante de preocupación (VOC [variants of concern]) o una variante de interés (VOI [variants of interest], por sus siglas en inglés, respectivamente), y debido a sus atributos y características compartidas, pueden requerir determinadas acciones de salud pública.

\footnotetext{
* Postgrado en Endoperiodontología. Editor en Jefe de la Revista ADM. México. 
La cepa es cada uno de los nuevos virus o especies (coronavirus) que surgen de mutaciones drásticas en su carga genética (SARS-CoV y SARS-CoV-2). Por lo tanto, las vacunas desarrolladas para combatir la COVID-19, seguirán siendo de gran utilidad para la cepa del SARS-CoV-2 y sus variantes. En cuanto a la aparición de mutaciones del virus, es difícil que se logre un «escape inmunológico», sólo algunas nuevas cepas podrían evadir la inmunidad que producen las vacunas o la propia infección del virus, pero a la fecha no hay más datos científicos. Las vacunas de mRNA anti COVID-19 se han destacado por su elevada eficacia frente al coronavirus superior a 90\%-, dicha eficacia está atribuida al virus original. Los científicos utilizan un proceso denominado secuenciación genómica para descifrar el material genético de un organismo o virus. Las secuencias de muestras obtenidas pueden compararse para ayudar a un seguimiento de la propagación de un virus, cómo está cambiando y cómo dichos cambios pueden impactar en la salud pública (Tabla 1).

\section{¿ES ÓMICRON EL FINAL DE LA HISTORIA EVOLUTIVA DEL SARS-COV-2 O SIMPLEMENTE UN GIRO EN LA TRAMA?}

Durante la pandemia de COVID-19, las sesiones por Zoom han sido grandes aliadas de comunicación familiar, laboral y científico. A finales de diciembre de 2021, más de 130 científicos internacionales de centros multidisciplinarios (Escuela de Medicina de Harvard, Hospital General de Massachusetts, Hospital Brigham and Women's, Instituto Broad, Universidad de Boston, Universidad de Massachusetts y países como: Estados Unidos, Sudáfrica, Botsuana, Inglaterra e India), se reunieron para discutir sobre la variante ómicron, la última variante de preocupación que se había extendido con altísimo grado de infectividad. Al momento de escribir esta historia, ómicron ya había alcanzado su punto máximo en muchos países, ahora con una subvariante hermana (ómicron BA.2) que había comenzado a afianzarse como la variante con más alta contagiosidad, al menos 10 veces más que la variante delta, y entre algunos cuestionamientos sobre las posibles mutaciones, en esta reunión los expertos dejaron aclaradas muchas dudas. En ese sentido, ómicron puede no ser el final de la historia evolutiva del coronavirus, sino simplemente un giro en la trama epidemiológica. De hecho, al comienzo de la pandemia, el SARS-CoV-2 acumuló alrededor de dos mutaciones por mes, una tasa de cambio lenta que respaldó el pronóstico inicial de que el SARS-CoV-2 sería un virus de mutación lenta (Figura 1).

Las noticias de diciembre del 2021 sobre las mutaciones de ómicron, principalmente en la proteína S (spike o espiga), brindaron muchas esperanzas. Se describía altamente contagiosa, pero no más virulenta, sobre todo en las personas vacunadas. El coronavirus, sus mutaciones y variantes, en realidad no desaparecerán, la alta tasa de vacunación en muchos países, sumado a la rápida expansión de contagios por ómicron, han definido la probabilidad de estar al final de la pandemia. Pero recordemos que una epidemia es la propagación de una enfermedad rápidamente en una área geográfica. La pandemia afecta a más de un continente y los nuevos casos ya no serían importados, los nuevos casos son transmitidos comunitariamente. La endemia es la aparición recurrente de una enfermedad que mantiene una alta prevalencia en un grupo poblacional. Bajar la tasa de mortalidad puede ser un paso de la pandemia a una endemia, por lo que si una enfermedad se vuelve endémica no indica que está erradicada. Existen muchas enfermedades crónicas que son endémicas (sida, sarampión, tuberculosis, etcétera), y los casos por lo general se vuelven consistentes y predecibles, pero lo endémico no significa menos grave.

La pandemia todavía no es una endemia, el mundo en su conjunto, sin vacunación, está muy lejos del final de

Tabla 1: Resumen de las variantes de preocupación (VOC) del SARS-CoV-2.

\begin{tabular}{lll} 
Variante & Linaje & Situación \\
\hline Alfa & B.1.1.7 & Detectada en septiembre de 2020 en Reino Unido \\
Beta & B.1.351 & Detectada en mayo de 2020 en Sudamérica \\
Gamma & ..1 & Detectada en noviembre de 2020 en Brasil \\
Delta & B.1.617.2 & Detectada en octubre de 2020 en la India \\
Ómicron & B.1.1.529 & Detectada en noviembre de 2021 en varios países (África, Hong Kong, Israel, etc.) \\
& BA.2... (B.3) & \\
\hline
\end{tabular}

Las variantes lambda y mu han quedado relegadas a la categoría de variantes de interés (VOI). 


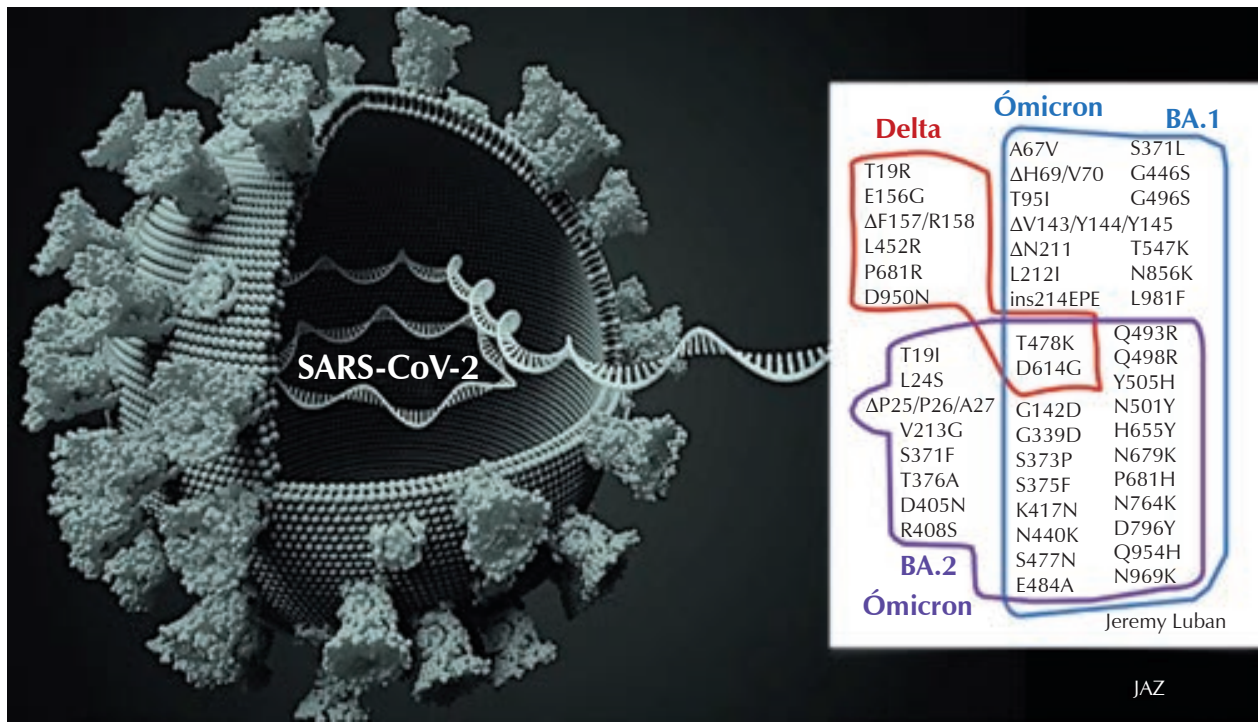

Figura 1:

Mutaciones superpuestas en las variantes delta, BA.1 (ómicron) y BA.2 del SARS-CoV-2. Los investigadores dicen que la evolución viral está en curso, y es probable que ocurran más mutaciones, dando lugar a nuevas variantes. Imagen: Jeremy Luban. la pandemia. En México es imprudente cantar el final de la pandemia. Y como dice una máxima de salud pública, nadie está a salvo hasta que todos estén a salvo.

Como corolario de las mutaciones basta el cambio de una letra en el código genético para expresar una variante. Y si una cepa cambia una letra, hemos encontrado una «nueva sepa». Sepa del verbo saber conjugado en primera, segunda y tercera persona de singular, presente en modo subjuntivo, así como en segunda persona de modo imperativo. Sepa usted que está invitado a la reflexión.

\section{LA NUEVA «SEPA» (JOSÉ MELAMED)}

Sepa que su cuerpo es una máquina perfecta que tiene la capacidad de regenerarse, desinflamarse, desintoxicarse, repararse y SANAR.

Sepa que tenemos más bacterias y virus que células humanas. Y que ambos son vitales para nuestra existencia y salud.

Sepa que toda enfermedad comienza en el intestino y que en su intestino se encuentra más de $70 \%$ de su Sistema de Defensas.

Sepa que el ayuno fisiológico es la Terapia Magna. Ayuda a que su cuerpo se enfoque en sus células inmunes, reciclándolas y deshaciéndose de las dañadas.

Sepa que su alimentación es su primer y mejor medicina. Y una suplementación adecuada ayudará a suplir deficiencias y a potenciar su sistema inmune.

Sepa que todo lo que come vibra y esa sintonía afecta su frecuencia energética de la misma manera que sus pensamientos y emociones lo hacen.
Sepa que el miedo debilita su sistema inmune y es el principal promotor de la enfermedad junto con el estrés crónico.

Sepa que los abrazos fortalecen su sistema inmune y suben sus defensas hasta el punto que puede protegerlo de los virus e infecciones.

Sepa que el respirar oxígeno estimula también su sistema inmunológico, reduciendo la posibilidad de padecer trastornos alérgicos, afecciones respiratorias y asma, favorece la oxigenación celular eliminando las toxinas del organismo y células muertas.

Sepa, iel Sol es SALUD! Aumenta el número de glóbulos blancos que conforman el primer escuadrón de defensa del organismo y son los encargados de protegernos en primer lugar contra una infección.

Sepa que caminar descalzo en la naturaleza (earthing) hace que el sistema inmune desintoxique su cuerpo a través de carga de electrones de la tierra, lo que genera anticuerpos para combatir resfríos y alergias, además de disminuir el riesgo de que el cuerpo desarrolle inflamación prolongada.

Sepa que la práctica diaria de meditación de la Palabra de Dios aquieta y clarifica la mente, proporciona paz interior y bienestar en general.

Sepa que hacer ejercicio físico descarga tensión física y emocional, y genera endorfinas.

Sepa que el miedo es lo que más enferma y el egoísmo su peor secuela.

\author{
Correspondencia: \\ Dr. Agustín Zerón \\ E-mail: periodontología@hotmail.com
}

